Article

\title{
Mute Sacrum. Faith and Its Relation to Heritage on Camino de Santiago
}

\author{
Piotr Roszak (iD)
}

Faculty of Theology, Nicolaus Copernicus University, 87-100 Torun, Poland; piotrroszak@umk.pl

Received: 31 December 2019; Accepted: 30 January 2020; Published: 4 February 2020

check for updates

\begin{abstract}
The problem of recognizing the true motivations of secular pilgrims is often experienced on the Camino de Santiago. The faith of pilgrims seems to be hidden under the cover of many behaviors of contemporary pilgrims. At the same time on the Camino de Santiago, there could be observed a significant change in how the sacred is perceived by pilgrims: their experience is more related to "time" or "relation/event", than "place". The clue is the correct notion of religiosity, which for Thomas Aquinas was not a set of contents, but the relation to the ultimate end. In this light, the heritage can speak and manifest its message, when the relation is reestablished. With this theological background, I will try to answer the main question about the explanatory dimension of faith, its relation to the meaning of heritage and art and I will offer two proposals for the renewal of the theological approach to pilgrimage.
\end{abstract}

Keywords: implicit pilgrimage; Camino de Santiago; faith; theology of pilgrimage; Thomas Aquinas

\section{Introduction}

The relationship between sacred and profane finds its privileged expression in Christian pilgrimage. It is concealed in the very etymology of the term peregrinatio, or "peregrination", which refers to the route crossing "through the fields", per-agros (Turner and Turner 1978; Coleman and Elsner 1995). This, in turn, suggests that the sacred is not understood as something given directly but disguised, unto which the route leads "through" other realities as well. In which types of relationships to objects of art refer to the sacred? However, in what way does the modern pilgrim relate to the religious heritage of the past? Is pilgrimage a simple encounter with this history as with a museum image or the "warming up" of the frozen sacrum that needs to be ignited on the pilgrim's side? What significance does faith have in experiencing a pilgrimage?

In this article, I will analyze the role of faith in the experience of pilgrimage, by adopting the Camino de Santiago as the reference point. Many pilgrims who travel to Compostela say that their motivation is not entirely religious and far from liturgical practice, although they admit some spiritual potential on the Camino. The main question is how they live and experience the heritage that was created by religious people living in the Middle Ages. To explain this, I will apply the distinction made by a 13th-century Catholic theologian, Thomas Aquinas, between explicit and implicit faith to the contemporary phenomenon of pilgrimage. Although Aquinas did not use these terms in the contexts of cultural heritage or sacred and profane experience, nevertheless I will argue that it can be a useful tool for theological reflection on pilgrimage. This kind of reflection requires a discussion of the meaning of religiosity that is operated in studies on pilgrimage and Aquinas' virtue of religion is applicable in this sense.

My intention here is not to focus on a detailed presentation of Aquinas' doctrine of religiousness, its manifestations or reception in history, but to apply his philosophical and theological principles to the Camino experience in order to shed light on the contemporary form of pilgrimage. Naturally, Thomas Aquinas did not write about Camino, but his thoughts on possessing an imperfect and perfect 
virtue might open insightful reflections on the state of the pilgrim's religiosity, in which religiosity is often not directly visible or performed in authorized, sacramental ways (see Di Giovine and Choe 2019). Therefore, this is not an exegesis of Aquinas' texts, but an application of his theory to real-life issues, which necessarily means a selective and not systematic reading of the scholastic author's texts.

In this article, I will rely on my personal experience from research on the history and theology of Camino de Santiago, as well as from the nearly 10 years that I spent as a priest in Villamayor de Monjardin (Navarra). Although I have done more social scientific publications on this (Roszak 2019; Roszak 2017a; Roszak 2015; Roszak 2011), here I want to speak more generally in the theological sense of pilgrimage. This is a perspective that is not confined to understanding how one religious group (e.g., Christians) experiences a pilgrimage to Compostela, nor it is about presenting confessional theology, but rather it is an approach that attempts to analyze more broadly the role of faith by those who travel to Compostela, regardless of their religious (or areligious) tendencies. Based on a Thomistic framework, this article attempts to show what the understanding of the sacred and profane is, and how one can interpret the hermeneutic function of faith and religiosity.

The Camino de Santiago is a route to Santiago de Compostela in northwestern Spain, where the tomb of one of the Apostles of Christ-Saint James, son of Zebedee-is located. The remains of James are kept in the original Roman mausoleum, where many traces of the authenticity of the relic and the early Christian cult (Alarcón 2017) have recently been found. In the early centuries, the pilgrimages were local, and since the ninth century, a dynamic development began which continues to this day (Vázquez de Parga et al. 1949). Nowadays nearly 300,000 people travel to this Spanish cathedral, and the road network runs practically throughout the European continent (Mróz 2019). At the same time, it is an example par excellence of European Catholic pilgrimage, as well as the conversion of historic religious pilgrimages into more secular heritage routes and sites in the contemporary era (Di Giovine and Garcia-Fuentes 2016). It was utilized by the Spanish dictator Francisco Franco as a national religious heritage site, by the European Union as its premiere "cultural route", and by UNESCO as a site of universal value for humanity. Exuding different forms of heritage, as well as faith, the Camino is important for understanding their interrelationship. The concept of implicit faith developed by Thomas Aquinas may be particularly useful in describing the relation of faith and heritage (Pesch 2001, p. 130). In this way, the theology of pilgrimage will be presented in the Christian perspective, which allows for an understanding of many contemporary paradoxes in, as well as the lack of visible religiosity on, the Camino de Santiago (Oviedo et al. 2014; Cesaux 2011).

\section{The Role of Faith in Understanding Pilgrimage}

The dynamic development of the philosophy of hermeneutics in the twentieth century has shown that in order to understand a given reality it is necessary to immerse oneself in the tradition from which it grows (Gadamer 1960). It is the horizon of understanding that opens up to cognitive access. Faith plays such a role in contact with works of art, which allows us to perceive ordinary things in a specific way (Cessario 1996, p. 11). Due to our cognitive limitations, the way to know is through relationships. Being in a relationship is a source of knowledge and a way of learning about the world (Berry 2017). That is why faith is not about solving intellectual dilemmas, but to establish a relationship with God (Schumacher 2015, p. 9). In a similar way, the various art objects present on the Camino lead to a relationship with the pilgrim (Roszak 2014; Moulin-Stożek 2019). Thanks to faith, the pilgrim establishes a relation with heritage, which introduces him to participation and discovers true meaning (Scarpelli Cory 2018). The first hermeneutic function of faith denotes the ability to give meaning through reference to the whole, and thus to the value of the true good (Platovnjak 2017).

The second function of faith is the capacity to harmonize, thus, not to create a new meaning or to impose things on it, but to restore the original rectitudo that existed in the original state of justice, which reigned in paradise (Houck 2016). It is the internal conformity of man, his intellectual and physical sphere, the harmony of the soul's authorities. It is not about eliminating the bodily element, but harmonizing as in music, and consequently using all elements of life and directing them towards 
the main aim. It is not about depriving certain elements of life but integrating according to the key values. As a result, the negation of the spirit of pilgrimage will be the experience of the Camino in the spirit of escapism, while some scholars (Cara 2018) even see in The Way the resistance to hypermobility, which builds identity through participation in this ritual (Van Der Beek 2017). The mentality of the Camino is to appreciate every minor gesture, to be accepted on the Way and the ability to confirmatio, thus the agreement of the will of God and the will of man, which is accomplished in love. After all, faith works through love, which leads to such a reconciliation, which does not sacrifice the one in the name of another but enables one to reach the target together. This is how Aquinas described the effects of God's love for man: it is his assimilation to God that respects his contingent nature. St. Thomas observed that God progresses in such a way to man, without modifying his nature but upraising its worth.

The third dimension of faith in the context of the religious heritage of the Camino is linked to the experience of universality, which opens up one form of heritage to a multitude of possible interpretations. It is the language of faith experienced by the pilgrim on the route of St. James, which leads to a kind of new Pentecost: many possible ways of expressing the same truth. It turns out that one faith is expressed in many languages, just like that day in Jerusalem at Pentecost, when everyone heard the message of salvation in their own language (Acts 2:6). It is like a beam of light that is fissioning, through a prism, into many different colors-though it is still the same white light. This stems from the theological conviction about the consequences of divine simplicity, which we are unable to express, because of its incomparability, unlike the multitude of ideas of always finite goods. In this way, judgments of truths constitute a structure that implies our relationship to the transcendent perfection of the Creator himself (Levering 2018, p. 53). Faith provides the pilgrim who meets on The Way the cultural signs of this "thinking according to the whole", which for Henry de Lubac was the core of catholicity (Lubac de 1988).

The fourth dimension of faith is its ability to purify because it is directed not so much towards external forms or means of expression (i.e., formulas of the profession of faith) as to the object (res) itself (O'Reilly 2013). Therefore, it leads to a constant effort of deepening, breaking through to successive layers, defining the path of spiritual formation and creating a specific supporting structure: it is a structure that holds the entire construction of the house together. The virtue of faith does not consist of getting accustomed to only one particular way of manifesting it, but because of the greatness of the divine truth is searching for new ways of expressing it.

Thanks to this capacity, when seeing a monument from the past, the pilgrim is able to separate the essence from its cultural manifestations characteristic for the given period (Romanesque, Gothic, modern, etc.). The message expressed in stone or on canvas is purified and recovered for the next generation (Bowman and Sepp 2019). Accordingly, faith is the ability to see more in things than they themselves express, purifying cultural mixtures, on the principle of cleansing silver mixed with lead. It is worth remembering that the experience of purification, in the description of the development of the way of faith was the first of the stages, followed by enlightenment (illuminatio) and unification (unio), as Dionysius Pseudo Areopagite formulated it (Louth 1989, p. 40; Lázaro 2006). The lack of faith can be felt by atheistic pilgrims, for whom it is more difficult to harmonize with the work of art; as Gadamer put it, they lack the 'hermeneutic environment'. Furthermore, by not participating in faith, they lose access to the knowledge of reality. For St. Thomas, faith is not a simple opinion on religious topics (such may atheists have), but participation in the confessed reality, thanks to which eternal life begins on earth (Roszak 2016).

Applying a Thomistic understanding of faith to pilgrimage requires a well-developed capacity for imagination (Steeves 2016). This is a consequence of the nature of the virtue of faith, which for Aquinas is the act of reason (directed towards the truth) under the influence of will (seeing the good in truth) attempts to begin the path from comprehensio, thus a partial approach to apprehensio, which is the possession (always in line with its being even in heaven and transformed by grace) of eternal truth. Faith needs analogy for its development, and in accordance with that the imagination to see more. 
From the perspective of the Catholic theology of pilgrimage, it is impossible to measure the religiousness of the Camino only in the form of religious practices, but demands that we pay close attention to the ultimate goal that man experiences through faith. For many, the Camino is a pre-pilgrimage, setting the stage for one's ultimate faith journey: his inability to control all of life (not everything depends on me), it is a long-term project (spiritual matters are reached by means of a certain mystagogy - Christian initiation, which is the task of the Church), and finally grace which gives difficulties and inconveniences on the way an opportunity to grow, since "power is made perfect in weakness". This is not just resilience, but the experience of the power of the Spirit, who, in respecting freedom leads to what is the ultimate goal (Delicata 2018).

\section{The Camino de Santiago de Compostela: What Happens to Religiosity on This Route? Is It Increasing or Decreasing?}

The Camino de Santiago is an appropriate example of how faith is a good operational category for exploring pilgrimage. It is a route, which pilgrims with varying intensity have followed for 1200 years. It possesses many variants depending on where the pilgrim starts: the most popular is the French Route, but also the Portuguese, Via de la Plata, Camino Primitivo or Camino del Norte. However, it is not confined to the Iberian Peninsula: the Camino network begins at the doorstep of the pilgrim's home, and then in the countries across Europe signs of the shell and the yellow arrow are found (Mróz et al. 2019).

According to the Christian tradition, St. James was buried in the place where he preached the Good News, where after his death he would be like a grain thrown into the earth, which brings abundant yield (Kotecki 2017, p. 107). During those early centuries, pagan Rome persecuted Christians, and thus the tomb is not widely known and even hidden by regional Christians, who nevertheless made local pilgrimages. Later times brought along a rivalry for primacy between Toledo and Santiago and attempts to undermine the authenticity of the place of the tomb of the Apostle James (Priego 1994, p. 82). Nevertheless, the existence of a cemetery around Compostela, as well as churches dedicated to James seems to confirm the existence of local worship (Barral 2016; Herbers 2020). The climax was the discovery of the forgotten tomb by Pelayo and the notification of King Alfonso II of Asturias ("The Chaste"), which passed into history as the inventio Sancti Iacobi (Baliñas 2017, p. 81). The following centuries elapsed in rivalry and battles to regain the Iberian Peninsula from the hands of Muslims, but at that time the place was frequented by many pilgrims, which is confirmed by the Arabic chronicles and the fact that Almanzor plundered Compostela.

Because of the rank of the Apostle's relics, Compostela was considered a so-called major pilgrimage, along with Jerusalem and Rome. Spiritual fruits in the form of indulgences could be obtained equally with these two important places for Christianity. Due to the size of the pilgrimage movement, international law ("Siete Partidas") came into being, roads were built, and a sense of community among European nations was born. Migrations often used the routes established for the Compostela as well. The Cistercian movement from Cluny (famous by its attempt to reform the medieval Church) took a huge role in this process of building the unity of Western Christianity (Rucquoi 2010). At the end of the Middle Ages, together with the so-called "modern devotion", the platonizing trend begins, which depreciates physical exertion and considers it the most important spiritual experience. It is possible not to move from one's place and yet experience a pilgrimage - there is resistance to wandering, which will be strengthened by nominalistic radicalism and criticism of the worship of the Saints brought by the Reformation. However, the pilgrimages have not disappeared, as evidenced by many documents from the 17th century, where not only expeditions to Santiago are confirmed, but so are actions against pilgrims who are accused of espionage (Rucquoi 2018).

A clear sign to revive the Camino route was the visit of Pope John Paul II in Compostela in 1982 and the call of Christians to return to the trails leading to this sanctuary. The numbers issued of "Compostels" are eloquent in this respect and indicate the role of the pope's visit. Another visit of John Paul II in 1989 and the World Youth Day held in Santiago de Compostela that year definitively sealed 
this project. This was met with criticism from several French left-wing movements that joked about the "Pope's dream about the Compostela", which John Paul II himself mentioned in his book, Crossing the Threshold of Hope (Paul II 1994, p. 116). The dream, however, turned out to be a reality. Since then, a mass pilgrimage movement began, which resulted in a phenomenon characteristic of all processes on such a large scale, and at the same time accompanied by cultural changes taking place in Europe, as well as diagnosed among others by Zygmunt Bauman (Bauman 1996).

\subsection{Lost "Sacrum"?}

Today, there is a conviction that the religious dimension is being lost in Christian pilgrimage (Amaro et al. 2018). I believe, however, that it is not so much the erosion of the sacred, but the alteration of the manifestations of religiosity, leading to a somewhat "taming" of the sacred, which for some gives the impression of the elimination of the sacred (sacrum). Paradoxically, this leans towards the fundamental question about the significance of religiosity, not so much in the post-secular context, as to regain the medieval importance of religio, which dominated in the times of the dynamic development of the Camino de Santiago in the Middle Ages (Rucquoi 2018). Religiosity did not rely on a catalog of specific activities that were labeled simply as "religious" due to their belonging to a certain category of action. For Aquinas, religion was a virtue that governs the means towards the final aim and belongs to the virtues that derive from justice (religio consistat tantum in ordine ad Deum, as Aquinas affirms in Summa Theologiae II-II, q.81). According to Aristotle, it is happiness, which consists of the most perfect activity of the most perfect human authorities, i.e., the contemplation of God. ${ }^{1}$ In this sense, religiosity is a certain configuration of natural matters, not the creation of new elements or classes of activities labeled as purely religious. On the contrary, everything in such a context could possess a religious character, if it served to achieve the definitive and ultimate: from marching, by preparing a meal, to praying in the temple and participating in the liturgy.

Due to the relational nature of religiosity and faith, both terms play a special role in relation to heritage, since they purport to shed light on the true significance and value of these objects. These, in turn, gain importance in the context of the whole and do not carry their sense in the isolated singularity (Vargas Herrera and Marchant 2018). All this, however, demands a new understanding of the sacred, which is linked with the withdrawal from the Platonic paradigm (ideas existing separately and autonomously, Lafargue 2016, p. 20) for the benefit of the Aristotelian where ideas are in things (Doolan 2008). These two mentalities seem to occasionally seize discourse in the theology of pilgrimage (Woolgar 2018). I am convinced that the Aristotelian-Thomistic approach, which demonstrates that there is no accessible "pure sacrum", as independent of things but always mediated in reality (Aquinas 2012, p. 104: intelliguntur enim spiritualia per sensibilia), seems to correspond better to both the evangelical messages and the post-secular sensitivity. Therefore, the Christian vision of pilgrimage was focused on reality-on what is genuine in existence, and not on what it may be or how God wanted it to be. The medieval understanding of pilgrimage was not based on idealistic metaphysics, which focused on the modalities of being, but it was realistic, attentive to the very existence. Medieval sermons which encouraged pilgrims to Compostela care for pilgrims, the rendering of works of mercy towards them, as well as the construction of hospitals, are perfect proof of this (Bériou 2018). In these sermons, the choice between going because of curiosity, the desire of getting to know the world, and the reverence for St. James does not have to be made: because of medieval realism, it is possible to reconcile both. The transition from one to the other is the work of spiritualistic theology, which undoubtedly was significant in the theology of pilgrimage (Honnefelder 2002).

1 Similarly, when someone drives a car to buy bread in the store and on the way he performs a number of actions during the drive, these actions remain in relation to what he does, although he can do something other than just think about bread (Jensen 2018, p. 18). He can talk about different topics along the way, stop to pay taxes, make a phone call to the workshop or to friends. At the same time, there are ongoing activities that are in relation to the goal. 
The sacrum could have been linked in different ways with the material reality (Cova et al. 2018): for some, in the Platonic tradition, they are two non-contacting realities, separated from each other; in other approaches, one contains the other, for example, when it is claimed that the material thing contains something sacred and indirect forms, when matter refers to spiritual matters, as in the case of the sacraments in the Catholic Church, where the water in baptism evokes spiritual effects but is not sacred in itself ${ }^{2}$. It was largely due to a different kind of theological apprehension of the relationship between nature and grace: whether they were understood in opposition to each other, as two levels of one reality or grace were naturalized. How one responds to this depends on his or her attitude towards the sacrum. For Aquinas, grace is a gift given to man by God, which is not connected with any previous merit of man. Accepted by man, it makes him available for full contact with God (sanctifying grace) and by grace, God's help, he can do things that exceed his natural abilities (grace of deed), how to persevere in goodness and achieve eternal happiness (salvation). In this perspective, grace is not against nature but helps nature to go beyond nature itself.

\subsection{Towards a Renewed Understanding of Religiosity: Relational Sacredness.}

From the beginning, however, the Camino was characterized by the affirmation of the world that stemmed from a specific understanding of grace as an accident, metaphysically speaking, not substance. Grace is not "something" that comes down from heaven, on the principle of an object possessing its own existence, but by the improvement of man, it grants him the power to do something beyond his nature. Consequently, there is no need to choose between a pilgrimage, a heritage tour, or a curiosity about the world. The attitude of the pilgrim consisted of "through" one to the other. The religious experience of the route to Santiago was not a simple rejection of what was around, but the absorption and pursuit of the final aim.

Therefore, the Christian meaning of pilgrimage is the connection of man to his assumed goal in faith, which is indicated by one of the etymologies of the term religion, which in Latin is religio-a word derived from religare, or "to bind" (Hütter 2016). In this approach, faith does not help in solving intellectual problems that cannot be dealt with by reason only, which was typical for the Ancient Greek understanding of faith (Maspero 2018), but in being strong and connected to God in reality (Buber 2003; Roszak 2014). A certain analogy can be found in contemporary religious art, which in the domination of abstraction wants to convey that its religiosity does not consist in simply expressing biblical motifs, but demands a joining and tying of things with God, which is assisted by properly shaped spiritual and internal senses (Dohna-Schlobitten 2016; Gavrilyuk and Coakley 2011).

Additionally, by referring to things that are beyond the world, Christian pilgrimage is not confined to a walk from place $A$ to $B$, but suggests the existence of the transcendent $C$ which expresses and justifies everything that happens during the journey from $A$ to $B$. This means that the pilgrimage is a process involving all experiences taking place on the way to the pilgrimage site, and not just the "selected", labeled as religious (e.g., prayers).

The holistic approach to pilgrimage is experiencing its renaissance in modern anthropology of pilgrimage. For Victor Turner, pilgrimage creates communitas, a temporary, transcendent feeling of unity among all pilgrimage/ritual participants that transcends social classifications such as status, class, even gender (Turner 1969). However, for Eade and Eade and Sallnow (1991) the situation is different because pilgrimage is predicated on consultation and negotiation between individuals and groups. Nonetheless, these two opposing hypotheses agree with my argument that pilgrimage is the totality

2 Cova et al. 2018 studies the fragmentary relate to the Middle Ages due to the limitation to the X-XII century and do not answer the question why the relation between the sacred and the profane was characterized as mutually exclusive. The phenomenon described as fuga mundi ("refuge from the world"), in which the necessity of not dealing with the affairs of this world but only with eternal life was emphasized, which meant that the Christian ideal was to be enclosed in the monastery without coming into contact with the normal life, is not a characteristic of the intellectual climate of the Middle Ages, and moreover, does not involve the Manichean rejection of materiality. Christian theology in the Middle Ages was extremely severe towards the Manichean type of duality. 
of experiences in the movement between the two. The approach to pilgrimage as a process is a very common perspective not only among anthropologists (such as Simon Coleman and Hillary Kaell) but also sociologists (John Eade) and other contemporary scholars such as classicist Jas' Elsner (see, for example, Eade and Sallnow 1991; Coleman and Elsner 1995; Kaell 2014; Di Giovine and Picard 2015; Warfield and Hetherington 2018).

Pilgrimage is the purification of sight to see what is taking place through conversion-metanoia, which means a change in the way of thinking and perceiving the world, its valuation (Alonso 2010; see also Di Giovine 2013). This conversion experienced during the journey is not a moral remodeling, but a new vision of things around, participation in them and restoration of the whole (Swatos 2009). At the same time, the nature of things contemplated in a new way does not change ontologically but establishes relations that create order (ordo). For example, just as the presence of many books does not create a library, but only their mutual relations and order (e.g., alphabetical) organizes their presence in a given place, so it similarly causes conversion: it does not add anything new but creates a new quality from what has been experienced. For such an ordo to be formed, a multitude of elements is needed as well as a clear criterion of division-ratio, as medieval theologians would say.

For this reason, the main focus in contemporary debates on pilgrimage is on the relational sense of sacredness (Di Giovine and Choe 2019), which fundamentally indicates a source of meaning for human beings (Oleksowicz 2018). In contrast to previous epochs, the sacrum is not sought in a specific place, as if it was related to a piece of terrain, but the modern theology of pilgrimage (Lopez 2014) draws attention to the categories of 'time', in the sense of experiencing moments in a specific place (Rennie 2017; Duda and Doburzyński 2019). Many pilgrimage diaries of the Camino do testify about this qualitative change, in which the standing within specific square meters does not matter so much as the survival of time: they do not pay attention to things or descriptions of buildings (as in medieval guides) but to people and situations (Nilson 2000). In this way, sanctuaries become not so much "something that stores holiness" in the objective sense, but the relational attachment of the pilgrim to the fundamental. This new trend, referred to as post-secular tourism, can bring a lot of interesting inspiration to the theology of pilgrimage, as transcendent traditional dichotomies between religious pilgrimage and tourism (Di Giovine 2013, p. 70; Nilsson and Tesfahuney 2017).

The contemporary pilgrim, as it is demonstrated by the Camino and the statements of pilgrims, does not experience holiness as "something" local, but the geographic concrete helps to create a network of relationships thanks to the meeting with relics. They themselves are not sacred, but what they evoke: the connectivity of man to the ultimate goal-salvation-is sacred. Sacrum becomes invisible, like a magnetic field that is formed-it is always based on magnetic poles, specific places, but it revives and generates a spiritual force when man establishes relationships. Pilgrimage thus becomes an opportunity to regain lost or loosened relationships. For this reason, the journals of pilgrims often pay much attention to these new relationships and have become the subject of separate research (such as the PILNAR project in the Netherlands). ${ }^{3}$

The Camino is today a catalyst for a specific "taming of the sacred": it is not a simple encounter with the sacred, but the construction of relationships through that which is visible and tangible: its heritage activates, like an ignition, the entire spiritual process which according to the convictions of Thomas Aquinas always begins from what is material: there is nothing in the intellect, which would not have been in the senses earlier. Therefore, what is spiritual is not given "directly", as if it could be separated as a kind of "zone of the sacred": it is reached through manifestations, i.e., sensory carriers. Mystical experiences provide an exceptional situation, although they (as well as prophecy) contain mediation (e.g., imaginations).

For that reason, in the majority of the pilgrims' descriptions of the Camino, religiosity is not always clearly perceived, but instead ordinary pictures dominate their accounts: fatigue, conversations

3 https://dev.clarin.nl/node/1945. 
with others, common meals in albergues, etc. Being a pilgrim signifies, by definition, the way to "something": piercing through what interferes in reaching what is the most important. Thus, according to Tertullian in his De carne Christi (Romero Pose 2006, p. 299), the essence of pilgrimage was, in the model of Virgin Mary, to reach Christ who was surrounded by a multitude of people and yet His Mother was able to do it (cf. Luke 8:19).

In this way, when we ask what (still) matters in Camino, the answer seems to emphasize that part of the human experience of going through matter to the spiritual. Hence, we can say that this pilgrimage is a kind of "sacrament": it does not focus on itself but refers and urges to exceed. ${ }^{4}$ Accordingly, one's very entering on the path of pilgrimage itself is a process of transformation, even if noticeable changes may not be observed for a long time, it is a hidden process, just as a plant that matures for a long time underground (Testoni et al. 2016). The pilgrimage becomes a sacrament, a sign that evokes grace, which initiates the path and revives dead symbols (Roszak 2017b).

\section{Understanding the Camino Pilgrimage through Thomas Aquinas' Notion of Implicit and Explicit Faith}

Consequently, contemporary pilgrims' motivations-or at least the difficulty in identifying them-do not imply a lack of religious reference or disbelief in the sacred (Frey 1998). It is worth recalling here an interesting concept developed by Thomas Aquinas, which may be the key to capturing the pilgrim's relationship to external manifestations of faith (temples, shrines, etc.), which modern research on the motivation of pilgrims seem to underestimate.

Aquinas distinguished two forms of faith: explicit (fides explicita) and implicit (fides implicita) when the desires of man are not concrete but included in his other activities. This implicitness evokes the image of unrolling the scroll in which the text was rolled up: to explicate is to reveal the implications that are there, though in embryonic form (Schultes 1920). For instance, in relying on rescue or salvation, those who lived before the coming of Christ implicite expressed their faith in the Redeemer who was yet to come. In the time of the Old Testament, there was no need to openly call Christ as the Savior: it was enough that man was aware that he cannot manage on his own, that there is no self-salvation. Someone believes "implicitly" when he does good and knows that the strength to perform it does not come from him alone. Although this distinction on explicit and implicit faith originally referred to the specific situation of people living before Christ's coming, and Aquinas clearly indicates that after the Incarnation it is necessary to believe in Christ directly, nevertheless it can serve as a general framework for Aquinas' theological thinking.

Hence, everyone remains in some relation to Christ: some as to the awaited one, others to the one being present in the body, and yet others as to the one that will come again in glory. From this perspective, it may not come as a surprise that St. Thomas will argue that the Old and New Testaments simply contain "the same" faith. By expressing this in his conceptual categories: res is the same (=essence), while the difference concerns ennuntiabilia, i.e., the way of expressing this element (Summa Theologiae II-II, q. 1 a. 2 ad 2). Besides, this was crucial for his concept of faith-the act of faith does not concern word formulas but the content that these language vehicles express (Roszak 2014). The object of faith is not the creed formulas established by the councils, but what is indicated in them. That is why St. Thomas asked whether there are truths in every age, in which everyone must believe explicitly or not, thus expressing the belief in the development of the doctrine (Kaczor 2001). Indeed, faith is not something of the same in every age, somewhat ready-made, which on the principle of a brick is transmitted from hand to hand. Faith is the answer to the revelation of God and the relationship with him: in this way, faith is built on religiosity and develops it.

4 It is worth adding that in the Catholic tradition the sacraments are effective signs of invisible grace: e.g., baptism through visible immersion in water, gives the grace of being incorporated into the Church as the mystical Body of Christ and into new life. The idea of the sacrament wants to convey that although the material side (water) is seen, it is not about a simple wash of temporal dirt, but a supernatural, spiritual wash of sins, especially original sin (Lynch 2014). 
For Christians, Aquinas argues in the Summa Theologiae II-II, q. 81, a. 5, the essence of the virtue of religion cannot be separated from its manifestations (prayer, sacrifice). However, Thomas emphasizes that possessing a virtue is always dynamic, not static. That is why Aquinas distinguishes different stages of possessing a virtue: there is a true but imperfect virtue (vera virtus sed imperfecta) or perfect virtue (simpliciter perfectae) oriented towards the ultimate goal which is God. As a moral virtue, connected to the virtue of justice, religion inclines man's will to render unto God the worship he is due as the first principle of all beings. It is distinct from the theological virtue of faith that has God as an immediate object. Nevertheless, some acts of the virtue of religion can be caused by the faith of someone, i.e., the adoration that someone expresses believing in Christ's presence in Eucharist (as Aquinas indicates in Summa Theologiae II-II, q. 81, a. 5, ad.1). However, it is still moral virtue, not theological.

To believe implicitly denotes that it is difficult to clearly judge only in accordance with external indications since one act can express the same thing differently. This metaphysical rule allows Aquinas to capture it better because something is present not only when it takes place in the act, but also in the possibility of becoming something else. The point is that one activity implicitly hides another: by watching a colorful object, simultaneously (though not directly) we affirm the light which makes such and not another color possible (Scarpelli Cory 2013, p. 137). ${ }^{5}$ Similarly, in every good done by saints before the coming of Christ, the promise of His goods can be observed. ${ }^{6}$ In this context, both the concealing of real motives and bringing them only to trekking or excursions which so often emerge on the Camino de Santiago can be understood: it is the reference to external activity, in which, however, something else, something essential is hidden (Farias et al. 2018). Pilgrimage from this perspective is a manifestation of the pilgrim in what implicitly expressed his decision to go to Santiago and bear many hardships (Bailey 2001). Many pilgrims, when talking about their motivations for undertaking a pilgrimage, indicate what is most visible and direct, e.g., the desire to find ways of coping with difficult decisions such as getting a divorce (Chemin 2011, p. 219). ${ }^{7}$

Therefore, if the quasi-sacramentality of the pilgrimage is approved, it can be possible to distinguish, just as classical theology did, the material aspect from the formal: the first describes the common qualities for the class of beings, while the second, what distinguishes it from others, determines the specificity and uniqueness (Menke 2018; Boersma 2009; Gustafson 2019). Pilgrims, who wander in the spirit of the secular pilgrimage, in a material sense possess the same experience, after all, they follow the same path, describe the same places, experience similar things, but they differ in "form". It may be said that they do not put these elements together to form a whole, but maintain them as a conglomerate of parts. As a car is a collection of parts, but thanks to its form it constitutes a new quality, and thus a certain "whole" - it is by analogy that faith makes the pilgrim build a certain order from those experiences that refer to the ultimate goal, which is salvation. Otherwise, there is an "empty" pilgrimage that does not bring spiritual potential.

Thereby, we come to one of the functions of faith which revives the "frozen" sacrum hidden in the heritage: faith with its hermeneutic force makes man enter the path described by Aquinas as deductio.

5 Thomas Aquinas, Contra Gentiles, lib. 1 cap. 76 n. 2. “Omnis enim virtus una operatione, vel uno actu, fertur in obiectum et in rationem formalem obiecti: sicut eadem visione videmus lumen et colorem, qui fit visibilis actu per lumen. Cum autem aliquid volumus propter finem tantum, illud quod propter finem desideratur accipit rationem voliti ex fine: et sic finis comparatur ad ipsum sicut ratio formalis ad obiectum, ut lumen ad colorem".

6 Thomas Aquinas, Super II Thes., cap. 2 1. 1: "omnia bona et virtutes sanctorum, qui praecesserunt Christum, fuerunt figura Christi".

7 Many pilgrims do not come back with a direct mystical experience (spiritual, supernatural approach), yet, just because they do not speak directly about this religious experience does not mean that it was not there. It was hidden in their experiences, which they tell about afterwards on pilgrimage meetings (admiration with which they admired the surrounding nature, meetings with others, questions asked etc.), when they show photos, remember how they walked. They themselves point out that something has changed, although they have difficulty naming it, and therefore a theological dictionary is needed to help make explicit what is contained in the experience. Thomistic faith does not add anything to these experiences from the outside, but there is a discovery of networks. A bit like connecting dots with each other, in a child's exercise, so that a picture emerges from them. You have to combine them to see the whole thing. 
This deduction is the inference from the general to the particular, the discovery of meaning in the context of a larger whole, and for this faith is capable. It provides what the scholastics called ordo, an order: mutual interrelations of elements make it a coherent whole. Just as books themselves do not constitute a library, but only when they are linked according to a certain order. Faith introduces order and in this way does not so much impose meaning, but interprets it in a broader context.

At the same time, this process is possible in the opposite direction: from external manifestations of faith (images, figures, churches) it can be extracted-deduced-faith. It is never given in the pure form, but it always seems to be given in solution, mixed with other elements. Pilgrimage is a reverse process for dilution: it is the precipitation of elements from the solution (i.e., culture) in order to capture a group of essential components. The role of faith in facing the monuments of the past is the recovery of meaning, providing the power of explanation, hermeneutics, and the binding together of dispersed contents. Faith is like a pattern that enables us to put together all the puzzles: when we buy puzzles, we get a picture according to which we should arrange everything.

The essence of pilgrimage in this perspective is to direct man to salvation understood as the persistence in possessing the good, bringing it to its fullness in life. Man is, in Christian terms, created to achieve union with God, but the path leading to this union can only be walked through with cooperation with grace, by accepting it freely. In this context, pilgrimage appears as a sign that refers to this macro-perspective of life. That is why it has been valued as a kind of testimony that life is heading somewhere, and not just spinning around. The pilgrimage to the tomb of St. James, with its accompanying elements (visiting the relics) was an exemplification of the life path of the Christian, who reaches Christ, through His Saints. What happens along the way is valuable as well-not only the achievement of the goal: the grace of pilgrimage is revealed in the hardships of everyday life, which shape the spiritual side of the believer (Harris 2019). These background elements have power due to this direction towards salvation, which organizes everything else, on the principle of a leading melodic line as in Bach's fugue.

Nevertheless, there may also appear a phenomenon that Bernhard Welte once described in his discussion of "unwesen" (non-essence). Many phenomena, including religious, are exposed to a slow shifting of interest from what is significant to what is marginal. This occurs when the central truth is displaced by the truths located on the peripheries. Focusing on what is visible and direct, just like on the means towards the goal, makes the "inner being" move into the background while maintaining the "external form". This can be seen in a number of religious celebrations, such as the sacrament of baptism, in which the setting and customs accompanying the sacrament (family gathering, festive dinner, etc.) cover the meaning of this rite: all this comes from oblivion, which went to the center of philosophical reflection together with Heidegger (Woźniak 2013, p. 42; Horvat 2017).

\section{Conclusions}

In the face of these phenomena, the question concerning the Camino's religious heritage also arises, scattered along the route not only in Spain but also in many countries of Europe (Mróz 2017), which the pilgrim has a chance to get acquainted with on the Way of St. James. Many scholars ask, how can wandering on the Camino be considered a form of religious activity? How the monuments of the past affect those who do not profess the Christian faith? Do they matter to them?

An inspiring answer to these questions concerning faith and cultural heritage of the Camino may be the parable of Jesus about the treasure hidden in the field (Matt 13: 44-46). To acquire the treasure the knowledge about the value of this terrain is essential, and not to treat it as one of many. Simple admiration is not enough, but a commitment that ultimately leads to a "purchase" is necessary. Owning the land together with the treasure is an evangelical image of faith that gives the pilgrim something more than admiration for the relics of the past. It is the participation that leads to a better understanding (1), integration (2), seeing in the context of the whole (3) and revealing deep structures (4). This becomes the experience of the pilgrim when he makes the effort to wander to the tomb of St. James with the virtue of faith. 
In the distinction between the material and formal side, attention was drawn to the role of faith in the encounter with heritage, thanks to which ontology is not modified (which it is by its very nature). Faith, in being a formal factor, inscribes heritage in a network of relations and allows us to discover a meaning that can not be found on the micro-scale. At the same time, a proper understanding of sacramentality is extracted, which perceives "something more" in things than what is seen: this is an encouragement to exceed and discover the transcendental sense of the Camino de Santiago.

Funding: This article uses information gathered through the grant "Camino de Santiago and Tomb of St. James: from history to hermeneutics of faith" (2013-2017) funded from resources of the National Science Center (NCN) in Poland, allotted following the decision no. DEC-2013/10/M/HS1/00548.

Acknowledgments: The author wishes to thank Michael di Giovine, Mohammad Sharifi, Franciszek Mróz, Anton Pazos, Saša Horvat, Dorothy Adamiec for their patient reading of the manuscript and suggestions.

Conflicts of Interest: The author declares no conflict of interest.

\section{References}

Alarcón, Enrique. 2017. Paleo-Christian Inscriptions Dedicated to Mary in the Apostolic Tomb of Santiago de Compostela. In The Way of St. James. Renewing Insights. Edited by Piotr Roszak and Enrique Alarcón. Pamplona: Eunsa, pp. 9-28.

Alonso, Juan. 2010. La metánoia como lógica de la fe. Scripta Theologica 3: 585-61.

Amaro, Suzanne, Angela Antunes, and Carla Henriques. 2018. A Closer Look at Santiago De Compostela's Pilgrims through the Lens of Motivations. Tourism Management 64: 271-80. [CrossRef]

Aquinas, Thomas. 2012. Commentary on the Letter of Saint Paul to the Hebrews. Translated by F. R. Larcher. Edited by J. Mortensen and E. Alarcón. Lander: The Aquinas Institute for the Study of Sacred Doctrine.

Bailey, Edward. 2001. The Secular Faith Controversy. London: Continuum.

Baliñas, Carlos. 2017. The origins of the Inventio Sancti Iacobi and the making of the kingdom: A historical framework, 700-850. In Translating the Relics of St James: From Jerusalem to Compostela. Edited by Antón Pazos. London and New York: Routledge, pp. 75-87.

Barral, Alejandro. 2016. Locus Arcis Marmaricis oraz Mansio Asseconia. Toponimia enklawy archeologicznej Santiago de Compostela. In Camino Polaco. Teologia-Sztuka-Historia-Teraźniejszość, t. 3. Toruń: Wydawnictwo Naukowe UMK, pp. 9-26.

Bauman, Zygmunt. 1996. From Pilgrim to Tourist-Or a Short Story of Identity. In Questions on Cultural Identity. Edited by Stuart Hall and Paul du Gay. London: Sage, pp. 18-36.

Bériou, Nicole. 2018. Religion et Communication. Un Autre Regard sur la Prédication au Moyen Âge. Genève: Droz.

Berry, John. 2017. Christian Witness: Its Grammar and Logic. Biblica et Patristica Thoruniensia 2: 211-29. [CrossRef]

Boersma, Hans. 2009. Nouvelle Théologie \& Sacramental Ontology: A Return to Mystery. Oxford: Oxford University Press.

Bowman, Marion, and Tiina Sepp. 2019. Caminoisation and Cathedrals: Replication, the heritagisation of religion, and the spiritualisation of heritage. Religion 1: 74-98. [CrossRef]

Buber, Martin. 2003. Two Types of Faith. New York: Syracuse University Press.

Cara, Anthony. 2018. Walking as Resistance to Hypermobility: The Camino de Santiago Pilgrimage. Spiritus: A Journal of Christian Spirituality 1: 1-13.

Cesaux, Francois. 2011. To be a pilgrim: A contested identity on Saint James' Way. Turizam 3: 353-67.

Cessario, Romanus. 1996. Christian Faith and the Theological Life. Washington, DC: Catholic University of America Press.

Chemin, Eduardo. 2011. Pilgrimage in Secular Age. Religious and Consumer Landscapes of Late-Modernity. Ph.D. dissertation, University of Exeter, Exeter, UK.

Coleman, Simon, and John Elsner. 1995. Pilgrimage Past and Present in the World Religions. Cambridge: Harvard University Press.

Cova, Véronique, Julien Bousquet, Cylvie Claveau, and Asim Qazi Shabir. 2018. The changing dichotomy between the sacred and the profane: A historical analysis of the Santiago de Compostela pilgrimage. Journal of Management, Spirituality and Religion 1: 109-30. [CrossRef] 
Delicata, Nadia. 2018. Homo technologicus and the Recovery of a Universal Ethic: Maximus the Confessor and Romano Guardini. Scientia et Fides 2: 33-53. [CrossRef]

Di Giovine, Michael. 2013. Apología Pro Turismo: Breaking inter- and intra-disciplinary boundaries in the study of tourism and pilgrimage. The Journal of Tourism Challenges and Trends 2: 63-94.

Di Giovine, Michael A., and Jaeyeon Choe. 2019. Geographies of religion and spirituality: Pilgrimage beyond the 'officially' sacred. Tourism Geographies 21: 361-83. [CrossRef]

Di Giovine, Michael A., and Josep-Maria Garcia-Fuentes. 2016. Sites of Pilgrimage, Sites of Heritage: An Exploratory Introduction. International Journal of Tourism Anthropology 5: 1-23.

Di Giovine, Michael A., and David Picard. 2015. Seduction of Pilgrimage Sacred Journeys Afar and Astray in the Western Religious Tradition. Burlington: Ashgate.

Dohna-Schlobitten, Yvonne. 2016. Lasciarsi guardare. Antropologia filosofica e teologica dell'arte come preghiera. A partire da Romano Guardini. Ignaziana 21: 87-108.

Doolan, Gregory. 2008. Aquinas on the Divine Ideas as Exemplar Causes. Washington, DC: Catholic University of America Press.

Duda, Tomasz, and Dariusz Doburzyński. 2019. Religious Tourism vs. Sacred Space Experience: Conflict or complementary interaction? International Journal of Religious Tourism and Pilgrimage 5: 1-10.

Eade, John, and Michael J. Sallnow. 1991. Contesting the Sacred: The Anthropology of Pilgrimage. London and New York: Routledge.

Farias, Miguel, Thomas J. Coleman III, James E. Bartlett, Lluís Oviedo, Pedro Soares, Tiago Santos, and María del Carmen Bas. 2018. Atheists on the Santiago Way: Examining Motivations to go on Pilgrimage. Sociology of Religion 1: 28-44. [CrossRef]

Frey, Nancy. 1998. On and Off the Road to Santiago, Journeys Along an Ancient Way in Modern Spain. Berkeley-San Francisco-Los Angeles: University of California Press.

Gadamer, Hans-Georg. 1960. Wahrheit und Methode: Grundzüge einer Philosophischen Hermeneutik. Tübingen: Mohr Siebeck.

Gavrilyuk, Paul L., and Sarah Coakley. 2011. The Spiritual Senses: Perceiving God in Western Christianity. Cambridge: Cambridge University Press.

Gustafson, Hans. 2019. Pansacramentalism, Interreligious Theology, and Lived Religion. Religions 10: 408. [CrossRef]

Harris, Brennan M. 2019. The physiological effects of walking pilgrimage. International Journal of Religious Tourism and Pilgrimage 1: 85-94.

Herbers, Klaus. 2020. The rise of St. James' cult and the concept of pilgrimage. In Travel, Pilgrimage and Social Interaction from Antiquity to the Middle Ages. Edited by Jenni Kuuliala and Jussi Rantala. Abington and New York: Routledge.

Honnefelder, Ludger. 2002. La Métaphysique Comme Science Transcendantale: Entre le Moyen Âge et les Temps Moderne. Paris: Univ. de France.

Horvat, Saša. 2017. Heideggerov posljednji Bog. Bogoslovska smotra 4: 745-66.

Houck, Daniel W. 2016. Natura Humana Relicta est Christo: Thomas Aquinas on the Effects of Original Sin. Archa Verbi 13: 68-102.

Hütter, Reinhard. 2016. Happiness and Religion: Why the Virtue of Religion is Indispensable for Attaining the Final End. A Re-lecture of Thomas Aquinas with an Eye to His Contemporary Relevance. Nova et vetera 1: 15-60. [CrossRef]

Jensen, Steven. 2018. Sin: A Thomistic Psychology. Washington, DC: CUA Press.

Kaczor, Christopher. 2001. Thomas Aquinas on the Development of Doctrine. Theological Studies 62: $283-302$. [CrossRef]

Kaell, Hillary. 2014. Walking where Jesus Walked. American Christians and Holy Land Pilgrimage. New York: New York University Press.

Kotecki, Dariusz. 2017. "The Way of Faith" of St. James the Greater in the Light of the New Testament. In The Way of St. James: Renewing Insights. Edited by Enrique Alarcón and Piotr Roszak. Pamplona: Eunsa, pp. 107-36.

Lafargue, Michael. 2016. Rational Spirituality and Divine Virtue in Plato: A Modern Interpretation and Philosophical Defense of Platonism. New York: Suny Press.

Lázaro, Manuel. 2006. El acceso antropológico a la meditación con Dios en el "Tratado de Oración y Meditación" de san Pedro de Alcántara. Cauriensia 1: 237-49. 
Levering, Matthew. 2018. Tilting a Little More in the Direction of Thomas Aquinas. Pro Ecclesia 1: 48-55. [CrossRef] Lopez, Lucrezia. 2014. Riflessioni sullo spazio sacro: Il cammino di san Giacomo di Compostella (Spagna). Rivista Geografica Italiana 121: 289-309.

Louth, Andrew. 1989. Denys The Areopagite. London and New York: Continuum.

Lubac de, Henri. 1988. Catholicism: Christ and the Common Destiny of Man. Translated by Lancelot C. Sheppard, and Elizabeth Englund. San Francisco: Ignatius Pres.

Lynch, Reginald. 2014. The sacraments as causes of sanctification. Nova et vetera 3: 791-836.

Maspero, Giulio. 2018. Theologia Ancilla Mysterii: Epistemologia relacionale interdisciplinariedad. Scripta Theologica 1: 77-93. [CrossRef]

Menke, Karl-Heinz. 2018. Sakramentalität: Wesen und Wunde des Katholizismus. Regensburg: Verlag Friedrich Pustet.

Moulin-Stożek, Daniel. 2019. Pilgrim's Play on the Santiago Way. International Journal of Religious Tourism and Pilgrimage 5: 24-32.

Mróz, Franciszek. 2017. How Has Camino Developed? Geographical and Historical Factors behind the Creation and Development of the Way of St. James in Poland. In The Way of St. James: Renewing Insights. Edited by Enrique Alarcón and Piotr Roszak. Pamplona: Eunsa, pp. 59-80.

Mróz, Franciszek. 2019. Changes in religious tourism in Poland at the beginning of the 21st century. Turyzm 2: 95-103.

Mróz, Franciszek, Łukasz Mróz, and Alfred Krogmann. 2019. Factors Conditioning the Creation and Development of a Network of Camino de Santiago Routes in Visegrád Group Countries. International Journal of Religious Tourism and Pilgrimage 5: 56-71.

Nilson, Ben. 2000. The Medieval Experience of the Shrine. In Pilgrimage Explored. Edited by Jennie Stoppard. Woodbridge: Boydell, pp. 95-122.

Nilsson, Mats, and Mekonnen Tesfahuney. 2017. The post-secular tourist: Re-thinking pilgrimage tourism. Tourist Studies 2: 159-76. [CrossRef]

O'Reilly, Kevin. 2013. The Hermeneutics of Knowing and Willing in the Thought of St. Thomas Aquinas. Louvain: Peeters.

Oleksowicz, Michał. 2018. In search of the person. Towards a real revolution. Scientia et Fides 1: 229-62. [CrossRef]

Oviedo, Lluis, Scarlett de Courcier, and Miguel Farias. 2014. Rise of Pilgrims on the Camino de Santiago: Sign of Change of Religious Revival. Review of Religious Research 56: 433-42. [CrossRef]

Paul II, Pope John. 1994. Crossing the Threshold of Hope. New York: Alfred A. Knopf.

Pesch, Otto-Herman. 2001. Behold I am doing a new thing? History of Salvation and Historic Moments of Transition in Thomas Aquinas and Martin Luther. Science et Espirit 1: 123-42.

Platovnjak, Ivan. 2017. Vpliv religije in kulture na duhovnost in obratno [Influence of Religion and Culture on Spirituality and Vice-Versa]. Bogoslovni vestnik 2: 337-44.

Priego, Carlos C. 1994. Asturianos y mozárabes en los orígenes del culto jacobeo. In Los artes en el Camino de Santiago. Edited by Carlos Cid Priego. Oviedo: Universidad de Oviedo Servicio de Publicaciones, pp. 39-90.

Rennie, Bryan S. 2017. The sacred and sacrality: From Eliade to evolutionary ethology. Religion 4: 663-87. [CrossRef]

Romero Pose, Eugenio. 2006. Raíces Cristianas de Europa: Del Camino de Santiago a Benedicto XVI. Madrid: Editorial San Pablo.

Roszak, Piotr. 2011. Homo peregrinus. Kim jest prawdziwy pielgrzym? In Camino de Santiago-Nie Tylko Droga. Historia i współczesność Szlaku św. Jakuba. Edited by Piotr Roszak. Toruń: Wydawnictwo Naukowe UMK, pp. 21-41.

Roszak, Piotr. 2014. Credibilidad e identidad. En torno a la Teología de la Fe en Santo Tomas de Aquino. Pamplona: Eunsa.

Roszak, Piotr. 2015. The 'Prelude' to the Camino: The way of St. James and the cultural identity of Kuyavia and Pomerania. Compostellanum 3-4: 645-53.

Roszak, Piotr. 2016. Revelation and Scripture: Exploring Scriptural Foundation of sacra doctrina in Aquinas. Angelicum 93: 191-218.

Roszak, Piotr. 2017a. Camino de Santiago i granice. Migracyjny kontekst pielgrzymowania do Composteli. In Dziedzictwo Religijne i Kulturowe Drogi św. Jakuba—w 30. Rocznicę uznania Szlaku za Pierwszy Europejski Szlak Kulturowy. Edited by Piotr Roszak, Franciszek Mróz and Łukasz Mróz. Kraków: Czuwajmy, pp. 53-66. 
Roszak, Piotr. 2017b. Pilgrimage as sacramentum peregrinationis? Discovering the Ecclesiological Background of the Camino de Santiago. In The Way of St. James: Renewing Insights. Edited by Enrique Alarcón and Piotr Roszak. Pamplona: Eunsa, pp. 137-57.

Roszak, Piotr. 2019. Sacred and Space in Post-Secular Pilgrimage: The Camino de Santiago and Relational Model of the Sacred. International Journal of Religious Tourism and Pilgrimage 7: 33-40.

Rucquoi, Adeline. 2010. Cluny, el Camino frances y la reforma gregoriana. Medievalismo 20: 97-122.

Rucquoi, Adeline. 2018. Mille fois à Compostelle. Pèlerins du Moyen Âge. Paris: Belles Lettres.

Scarpelli Cory, Therese. 2013. Aquinas on Human Self-Knowledge. Cambridge: Cambridge University Press.

Scarpelli Cory, Therese. 2018. Embodied vs. Non-Embodied Modes of Knowing in Aquinas: Different Universals, Different Intelligible Species, Different Intellects. Faith and Philosophy 4: 417-46. [CrossRef]

Schultes, Reginald. 1920. Fides implicita. Geschichte der Lehre von der fides implicita und explicita in der katholischen Theologie. Regensburg: F. Pustet.

Schumacher, Lydia. 2015. Rationality as Virtue. Towards a Theological Philosophy. Farnham: Ashgate.

Steeves, Nicolas. 2016. Grâce à L'imagination. Intégrer L'imagination en Théologie Fondamentale. Paris: Les Éditions du Cerf.

Swatos, William. 2009. Pilgrimage and Conversion, in Conversion in the Age of Pluralism. Edited by Giuseppe Giordan. Leiden-Boston: Brill, pp. 115-30.

Testoni, Ines, Emilio Paolo Visintin, Dora Capozza, Maria Concetta Carlucci, and Malihe Shams. 2016. The implicit image of God: God as reality and psychological well-being. Journal for the Scientific Study of Religion 1: 174-84. [CrossRef]

Turner, Victor. 1969. The Ritual Process: Structure and Anti-Structure. Chicago: Aldine Publishing.

Turner, Victor Witter, and Edith Turner. 1978. Image and Pilgrimage in Christian Culture. New York: Columbia University Press.

Van Der Beek, Suzanne. 2017. Ritual identity. International Journal of Religious Tourism and Pilgrimage 2: 26-30.

Vargas Herrera, Francisco, and Loreto Moya Marchant. 2018. La espiritualidad como fortaleza humana y su relación con la construcción de sentido vital. Algunas notas específicas para el campo educativo. Cauriensia 13: 277-99.

Vázquez de Parga, Luis, José María Lacarra, and Juan Uría Ríu. 1949. Las Peregrinaciones a Santiago de Compostela. Madrid: CSIC.

Warfield, Heather A., and Kate Hetherington. 2018. Pilgrimage as Transformative Process. The Movement from Fractured to Integrated. Leiden-Boston: Brill.

Woolgar, Chris. 2018. What makes things holy? The senses and material culture in the later Middle Ages. In Sensing the Sacred in Medieval and Early Modern Culture. Edited by Robin Macdonald, Emilie Murphy and Elizabeth L. Swann. London: Routledge, pp. 60-78.

Woźniak, Robert. 2013. Zapomniane chrześcijaństwo: o zadaniu teologii fundamentalnej w kontekście wieku świeckiego. In U źródet Pamięci. O "Zapominaniu" w Historii, Teologii i Literaturze. Edited by Piotr Roszak. Torun: Wydawnictwo Naukowe UMK, pp. 39-53.

(C) 2020 by the author. Licensee MDPI, Basel, Switzerland. This article is an open access article distributed under the terms and conditions of the Creative Commons Attribution (CC BY) license (http://creativecommons.org/licenses/by/4.0/). 